\title{
Fleksibelitas Hukum Ekonomi Syariah
}

\author{
Murtadho Ridwan \\ Institut Agama Islam Negeri Kudus \\ murtadhoridwan@gmail.com
}

\begin{abstract}
This study aims to examine the flexibility of Islamic law in general and the flexibility of Islamic law in particular. This study is a literature review. Data is collected from various works that have been produced by the scholars and analyzed descriptively. The results of the study show that in general, Islamic law is divided into two types; First, Islamic law is static (fixed) and will not change, this type of law is based on Nash qath'i. Second, Islamic law that is flexible (dynamic) that can change according to the demands of the times, this type of law is based on the results of ijtihad. Many flexible laws are found in the law of muamalat (Islamic economics) and this has happened since the beginning of Islam. There are many examples of the flexibility of Islamic economic law, including: Umar stopped distributing the land from the war, even though the Messenger of Allah had distributed the land; Umar stopped the portion of the zakat property for the convert group even though they belonged to eight groups who were entitled to receive zakat shares; Umar made a policy to excise non-Muslim traders as big as Usyur (10\%) and Dzimmah Expert traders by 5\% when they entered the Islamic region; and Umar founded the Diwan (Baitul Mal) even though it never existed at the time of the Prophet.
\end{abstract}

Keywords: Islamic Law, Economic Law, Changing Law

\begin{abstract}
Abstrak
Kajian ini bertujuan untuk mengkaji fleksibelitas hukum Islam secara umum dan fleksibelitas hukum ekonomi syariah secara khusus. Kajian ini merupakan kajian pustaka. Data dikumpulkan dari berbagai karya yang telah dihasilkan oleh para ulama dan dianalisis secara deskriptif. Hasil kajian menunjukkan bahwa secara umum, hukum Islam dibagi menjadi dua jenis; Pertama, hukum Islam yang bersifat statis (tetap) dan tidak akan berubah, hukum jenis ini didasarkan pada nash qath'i. Kedua, hukum Islam yang bersifat fleksibel (dinamis) yang bisa berubah sesuai dengan tuntutan zaman, hukum jenis ini didasarkan pada hasil ijtihad. Hukum yang bersifat fleksibel banyak terdapat pada hukum muamalat (ekonomi syariah) dan hal itu sudah terjadi sejak masa awal Islam. Banyak sekali contoh tentang fleksibelitas hukum ekonomi syariah, diantaranya adalah: Umar menghentikan pembagian tanah hasil peperangan, padahal Rasulullah telah membagikan tanah tersebut; Umar menghentikan bagian harta zakat bagi golongan Muallaf meskipun mereka termasuk delapan golongan yang berhak mendapat bagian zakat; Umar membuat kebijakan untuk menarik cukai pada pedagang non-muslim sebesar Usyur (10\%) dan pedagang Ahli Dzimmah sebesar 5\% ketika mereka masuk ke kawasan Islam; dan Umar mendirikan Diwan (Baitul Mal) meskipun itu tidak pernah ada di masa Rasulullah.
\end{abstract}

Kata Kunci: Hukum Islam, Hukum Ekonomi, Perubahan Hukum 


\section{PENDAHULUAN}

Manusia adalah makhluk sosial yang hanya bisa bertahan hidup jika berinteraksi dengan yang lain. Manusia tidak dapat hidup sendiri, manusia saling bergantung dengan yang lain untuk memenuhi kebutuhan mereka. Interaksi sosial antar individu, antar kelompok, dan antar bangsa pada era globalisasi ini semakin mempercepat laju perubahan sosial. Dampak perubahan sosial dapat menimbulkan kesenjangan antara hukum yang sudah ada di masyarakat dengan realitas sosial yang berubah. Dan salah satu dampak dari perubahan sosial itu juga berpengaruh pada konsep serta pranata hukum Islam (Muhammad Khalid, 1999: 1).

Hukum Islam yang bersumber dari Alquran dan Sunnah merupakan tatanan dan peraturan Allah yang bertujuan untuk mengatur kehidupan manusia, namun keduanya memiliki daya jangkau yang terbatas. Turunnya Alquran sudah berakhir dan munculnya Sunnah sudah tidak ada lagi karena Rasulullah SAW telah wafat. Sedangkan peru bahan sosial dan permasalahan sosial selalu tumbuh berkembang dengan cepat, apalagi dalam bidang ekonomi, dan menuntut kepastian hukum.

Hukum Islam memiliki karakter statis dan fleksibel. Karakter inilah yang mengindikasikan kemampuan hukum Islam merespon dan menjawab setiap permasalahan yang baru muncul, khususnya dalam bidang muamalah (ekonomi) yang hukumnya tidak terdapat dalam Alquran dan Sunnah (Ibnu Rusy, 142). Dengan metode ijtihad, para ahli fikih dan cedikiawan Muslim dari berbagai disiplin ilmu berkumpul dan membahas permasalahan umat yang tidak ditemukan hukumnya dalam Alquran dan Sunnah. Mereka mengunakan segala daya upaya untuk menghasilkan hukum baru dan merekontruksi hukum yang pernah dihasilkan ulama sebelumnya untuk disesuaikan dengan kondisi zaman.

Kajian ini bertujuan untuk menjelaskan tentang fleksibilitas hukum islam karena perubahan waktu, tempat dan keadaan masyarakat, khususnya hokum yang berkaitan dengan ekonomi syariah.

\section{KAJIAN LITERATUR Hukum Islam}

Sebelum membahas tentang fleksibilitas hukum ekonomi syariah yang menjadi topik inti pembahasan, perlu dijelaskan tentang hukum Islam terlebih dahulu karena hukum ekonomi syariah merupakan bagian dari hukum Islam. Hukum Islam dalam bahasa Inggris biasa diterjemahkan dengan Islamic Law dan dalam bahasa Arab disebut dengan al-Syariah alIslamiyah (Syariat Islam).

Istilah syariat dapat memiliki arti luas dan juga arti sempit. Secara luas, syariat diartikan dengan segala yang diturunkan Allah SWT kepada Rasulullah SAW berupa wahyu, baik yang terdapat dalam Alquran 
maupun Sunnah yang kebenarannya tidak diragukan lagi (Jaser Auda, 2012: 22) Sedangkan arti sempit syariat sebagaimana yang dikemukakan sebagian ulama adalah segala perintah Allah yang berkaitan dengan perilaku manusia selain akhlak. Sehingga syariat merupakan nama lain bagi hukum-hukum yang bersifat amaliyah (Amir Syarifuddin, 2011: 41).

Istilah lain yang sangat erat dengan arti syariat secara sempit adalah kata fikih. Istilah fikih diartikan dengan ilmu tentang hukum-hukum syariat yang bersifat amaliyah, yang diambil dari dalil-dalil yang terperinci (Wahbah Al-Zuhaily, 1996: 19) Istilah syariat dan fikih dapat menunjukkan hukum Islam karena keduanya sama-sama membahas hukum Islam meskipun ada perbedaan mendasar dalam penggunaan.

Perbedaan mendasar antara keduanya adalah, syariat berasal dari Allah dan rasul-Nya sebagai pembuat syariat (al-Shari') karena syariat hanya mengandungi wahyu yang diturunkan kepada Rasulullah (Alquran dan Sunnah). Sedangkan fikih merupakan kandungan syariat yang diketahui oleh para ahli fikih atau mujtahid setelah mereka melakukan ijtihad ( Abdul Malik Wello, 2010: 114). Oleh karena fikih merupakan hasil ijtihad, maka fikih merupakan rumusan hukum Islam untuk diterapkan pada suatu kasus, di suatu tempat, keadaan dan masa tertentu.

Jadi, istilah hukum Islam di dalamnya mengandungi dua unsur; pertama, unsur hukum statis, artinya hukum tersebut selalu tetap di sepanjang masa. Hukum statis tidak mengalami perubahan ataupun pembaharuan meskipun zaman berubah dan diterapkan pada masyarakat yang berbeda-beda. Ketentuan hukum Islam yang statis telah dijelaskan dan ditetapkan Alquran dan Sunnah secara pasti, jelas, dan terperinci. Ketentuan hukum seperti ini tidak menjadi objek ijtihad. Hukum Islam yang memenuhi unsur statis tidak boleh berubah karena jika ketentuan hukum ini mengalami perubahan maka akan terjadi kerusakan (mafsadah) dalam kehidupan manusia, karena ia berkaitan dengan permasalah yang asasi (dharuriyah) (Yusuf Al-Qardhawi, 2001: 18-19)

Kedua, unsur fleksibel (dinamis), artinya hukum Islam dapat berubah sesuai dengan waktu, tempat dan keadaan dimana ia diterapkan. Hukum Islam yang bersifat fleksibel bisa berubah karena diterapkan di masyarakat yang berbeda meskipun waktunya sama. Hukum Islam yang bersifat fleksibel juga dapat berubah karena diterapkan di masyarakat yang sama, namun waktunya berbeda. Pemahaman terhadap hukum Islam yang menerima perubahan karena perubahan zaman, tempat dan keadaan sesuai dengan teori fleksibilitas hukum Islam yang dianut oleh mayoritas ahli fikih kontemporer, mereka mengikuti teori Maslahah dan juga Maqasid alShari'ah (Jamaluddin Athiyyah, 2003, 76)

Fleksibilitas hukum Islam dalam praktik menunjukkan bahwa hukum Islam bisa beradaptasi dengan perubahan sosial. Tanpa adanya 
upaya pembaharuan dan perubahan hukum Islam, maka akan kesulitan dalam menerapkannya. Di era global seperti sekarang ini, perubahan perilaku sosial masyarakat cepat sekali terjadi, termasuk juga dalam bidang ekonomi, sehingga perlu adanya satu tatanan hukum Islam yang mengatur perilaku sosial di masyarakat sesuai dengan tuntutannya. Maka, para ulama harus merespon untuk membuat rumusan hukum Islam sesuai kondisi sosial masyarakat (Muhammad Khalid Mas'ud, 1999: 23).

Ada dua ketentuan bagi hukum Islam yang bersifat fleksibel (dinamis); pertama, hukum Islam yang diambil dari Dalil Dzanni yang menerima perubahan, dan kedua, hukum Islam yang dihasilkan dari ijtihad akibat perubahan zaman.

\section{Kaidah Fikih tengang Perubahan Hukum}

Berdasarkan uraian tentang hukum Islam yang bersifat fleksibel (dinamis) tersebut, para ahli fikih membuat sebuah kaidah fikih yang

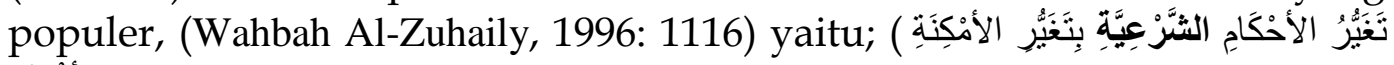
(وَالأزمِنَةِ yang artinya: "Perubahan hukum Islam sebab perubahan tempat dan waktu." (Ibnu al-Qayyim, 1998: 3)

Jika merunut literature Ushul Fikih dan buku Qawa'id, kita akan

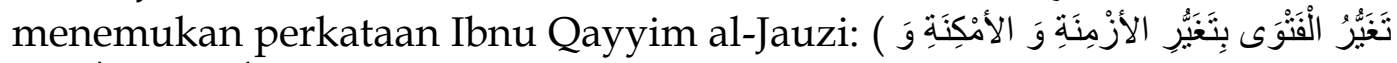
(الأحْوَالِ وَ الأعْرَافِ yang artinya "Sesungguhnya fatwa bisa berubah atau berbeda karena perubahan atau perbedaan waktu, tempat, keadaan atau kondisi, dan adat kebiasaan." Ibnu Qayyim berargumen bahwa prinsip dan dasar hukum Islam adalah hikmah dan kemaslahatan untuk umat manusia, baik dalam kehidupan dunia maupun kehidupan akhirat. Hukum Islam akan menciptakan keadilan, akan menurunkan rahmat, akan memberikan kemaslahatan bagi semua, dan akan mewujudkan hikmah. Setiap persoalan yang keluar dari keadilan hingga timbul kedzaliman, atau keluar dari kemaslahatan hingga mengakibatkan kerusakan, maka itu bukanlah syariat Islam ( Ibnu Al-Qayyim Al-Jauziyah, 1998: 3) Oleh karena itu, hukum Islam bisa berubah sesuai dengan perubahan waktu, tempat, keadaan dan adat kebiasaan sebagai upaya mewujudkan kemaslahatan umat manusia.

Perkataan Ibnu Qayyim dikembangkan oleh ahli fikih setelahnya

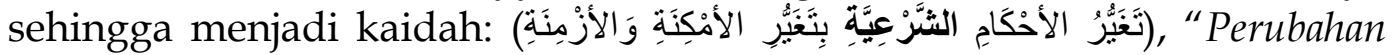
hukum Islam sebab perubahan tempat dan waktu." Namun kaidah ini tidak dapat diberlakukan secara muthlak, perlu ada rincian penerapan agar tidak bertentangan dengan aturan syara'. Ini karena, secara umum hukum Islam dikelompokkan menjadi dua seperti yang telah disebutkan.

Hukum Islam yang bersifat statis (tetap) bersumber dari Alquran dan Sunnah. Hukum Islam ini akan tetap dan tidak akan berubah serta tidak leka dengan perubahan sosial. Hukum Islam yang bersifat statis (tetap) ini tidak menjadi objek dari kaidah fikih ini. Contoh hukum Islam 
yang bersifat statis adalah kewajiban dan larangan yang disebutkan secara jelas dalam Alquran dan Sunnah seperti kewajiban solat, zakat, puasa, dan haji serta haramnya zina, khamr (minuman keras), membunuh, berbuat zalim dan larangan yang lain (Abdul Karim Zaidan, 1992: 43)

Hukum Islam yang bersifat fleksibel (dinamis) bisa berubah sebab perubahan waktu dan tempat. Hukum Islam yang bersifat fleksibel jumlahnya lebih banyak daripada hukum Islam yang bersifat statis (tetap), ini karena persoalan terus terjadi dan pembaruan terus berlangsung, apalagi dalam bidang muamalah (ekonomi) ( Abdul Karim Zaidan, 1992: 43) Maka hukum Islam yang bersifat fleksibel merupakan ladang ijtihad bagi para ahli fikih. Dan ini merupakan objek diberlakukan kaidah "Perubahan hukum Islam sebab perubahan tempat dan waktu."

Ulama fikih bersepakat bahwa hukum Islam yang bisa berubah karena perubahan tempat, waktu dan keadaan adalah hukum-hukum ijtihadi (hukum yang dihasilkan dari ijtihad). Objek ijtihad dalam hukum islam meliputi; hukum yang berdasarkan nash dzanni, hukum yang tidak ada nash-nya, dan hukum yang tidak disepakati ulama (tidak ada ijma' antara ulama). Jadi tidak ada praktik ijtihad pada hukum yang sudah jelas nash-nya karena termasuk dalam kategori hukum Islam yang statis ( Wahbah Al-Zuhaily, 1996: 1052) Di antara contoh hukum ijtihadi adalah, hukum yang didasarkan pada maslahah tertentu. Jika maslahah yang menjadi dasar munculnya hukum sudah tidak ada, maka hukum-pun akan berubah karena tidak ada illat atau alasan yang menjadi dasar bagi hukum tersebut.

Menurut Wahbah al-Zuhaily, ada beberapa faktor yang menyebabkan hukum bisa berubah karena perubahan tempat, waktu dan keadaan. Faktor tersebut adalah: (1) perubahan Urf (adat kebiasaan), (2) perubahan mashlahah umat, (3) untuk menjaga dharurah (keniscayaan), (4) kerusakan akhlak umat manusia dan lemahnya pemahaman agama, (5) perubahan tatanan sosial masyarakat (Wahbah Al-Zuhaily, 1996: 1052) Pada kondisi tersebut, maka hukum Islam harus berubah untuk mewujudkan kemaslahatan dan menolak kerusakan serta untuk menciptakan kebaikan dan kebenaran.

Sedangkan ulama lain berpendapat bahwa hanya ada dua penyebab yang mempengaruhi perubahan hukum Islam, yaitu:

1. Perubahan Urf (adat kebiasaan)

Hukum Islam dapat berubah karena ada perubahan Urf (adat kebiasaan masyarakat setempat). Al-Qarafi berkata: Hukum Islam yang dihasilkan dari adat kebiasaan akan berubah sesuai dengan perubahan adat kebiasaan tersebut. Hukum tersebut akan batal dengan sendirinya jika adat kebiasaan tersebut sudah tidak ditemukan lagi (Shihabbudin Alqarafi, 1987: 67) 
Ibnu al-Qayyim berkata: Sesungguhnya fatwa akan berubah sebab perubahan waktu, tempat, adat kebiasaan dan kondisi masyarakat. Semua itu berasal dari Allah, dan hanya kepada Allah lah kita meminta perlindungan ( Ibnu al-Qayyim al-Jauziyah, 9). Sedangkan Al-Zarqa berkata: Semua hukum yang didasarkan pada Urf (adat kebiasaan), maka hukum tersebut akan berubah sesuai dengan perubahan Urf (adat kebiasaan) tersebut. Ini karena, ada satu kaidah

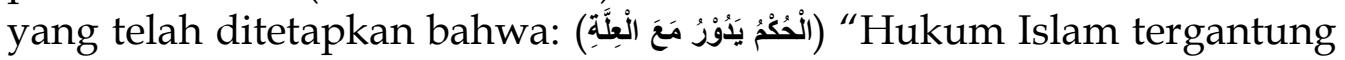
pada illat-nya". Dari kaidah itu muncul kaidah fikih yang menyatakan: "Tidak dapat dipungkiri bahwa hukum Islam bisa berubah sebab perubahan waktu" (Al-Zarqa, 2002: 89)

Oleh sebab itu, sebagian ulama berpendapat bahwa kaidah "Perubahan hukum Islam sebab perubahan tempat dan waktu,"

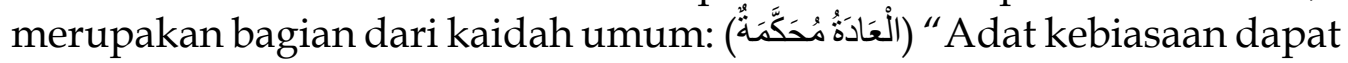
dijadikan dasar hukum". Jadi, jika sebuah hukum di dasarkan pada Urf (adat kebiasaan), maka hukum tersebut dapat berubah sebab perubahan adat kebiasaan yang ada di masyarakat. Sebagai contoh, Menurut alZuhaily, boleh mengambil upah atau gaji bagi guru ngaji Alquran, imam masjid, dan khatib solat Jumuat, hal ini karena adat kebiasaan yang telah berubah (Wahbah Al-Zuhaily, 1117)

2. Kerusakan akhlak umat manusia dan anggapan remeh terhadap hukum

Penyebab ini memiliki banyak contoh, diantaranya adalah riwayat yang dikatakan Aisha: "Jika Rasulullah mengetahui apa yang terjadi pada wanita, nescaya beliau akan mencegah mereka dari masjid" (HR. al-Bukhari). Aisyah berpendapat bahwa sikap wanita yang menganggap remeh cara berpakaian yang menyebabkan Rasulullah SAW melarang wanita pergi ke masjid. Artinya, jika Rasulullah SAW tahu jika wanita suka meremehkan cara berpakaian, nescaya beliau akan melarang wanita dari masjid. Hal ini karena kerusakan yang timbul akibat wanita meremehkan cara berpakaian secara benar, seperti memakai pakaian ketat atau tidak menutup aurat, akan lebih besar daripada maslahah (kebaikan) yang didapat wanita dari pergi ke masjid.

Dan masih banyak lagi contoh yang dapat menjelaskan kaidah ini yang ditemukan di literature fikih, diantara contoh tersebut adalah:

Pertama, Pada suatu waktu Rasulullah SAW melarang menyimpan daging kurban hingga tiga hari, beliau bersabda: "Barang siapa melakukan kurban, maka janganlah menyimpan daging kurban itu di rumah hingga tiga hari." Hadis ini melarang menyimpan daging kurban hingga tiga hari, Lalu di lain waktu, Rasulullah SAW bersabda: “Sesungguhnya aku pernah melarang kalian dari menyimpan daging kurban, maka makanlah, dan berilah makan (dengan daging kurban itu), dan simpanlah (daging kurban itu)." Hadis ini memberi petunjuk jelas bahwa fatwa bisa berubah sebab perubahan keadaan dan 
kondisi masyarakat. Artinya, pada suatu kesempatan Rasul memfatwakan untuk tidak menyimpan daging kurban hingga tiga hari, daging kurban harus segera dibagikan kepada yang berhak dan tidak boleh disimpan melebihi tiga hari. Namun di lain waktu Rasulullah membolehkan untuk menyimpan daging kurban (Yusuf Qardhawi, 1993: 184)

Kedua, Ijtihad Umar yang menambah hukuman orang yang meminum khamr (minuman keras), yang asalnya 40 kali cambukan ditambah menjadi 80 kali cambukan. Hal ini ditetapkan Umar karena masyarakat pada saat itu sudah menganggap ringan hukuman meminum khamr sehingga meminum khamr menjadi kebiasaan mereka. Lalu Umar berijtihad untuk menambah jumlah hukuman menjadi 80 kali cambukan agar tujuan disyariatkan hukuman dapat tercapai (Yusuf Qardhawi, 1993: 187)

Ketiga, Ijtihad Utsman yang menetapkan adanya adzan pertama pada solat Jumat. Hal ini dilakukan Utsman karena pada saat itu masyarakat disibukkan dengan urusan perniagaan sehingga terlewatkan solat Jumat. Adzan pertama dalam solat Jumuat merupakan sunnah yang pertama kali dilakukan pada masa pemerintahan Khalifah Utsman karena ada tuntutan untuk itu, ini bukan bid'ah. Namun untuk masa sekarang, banyak kelompok yang sudah tidak melakukan karena merasa sudah tidak ada lagi alasan untuk menjalankannya.

Keempat, Ijtihad para sahabat tentang perubahan kadar zakat fitrah. Pada masa Nabi, sebagaimana yang dijelaskan dalam sebuah hadis bahwa Rasulullah SAW mewajibkan zakat fitrah sebesar satu Sha' (4 Mud) makanan, baik berupa kurma, anggur kering (kismis), sya'ir, ataupun Aqith. Namun setelah itu, sejumlah sahabat seperti Utsman, Ali, Abu Hurairah, Jabir, Ibnu Abbas, Ibnu al-Zubair, dan Asma' binti Abu Bakar berpendapat bahwa setengah Sha' (2 Mud) gandum menyamai satu Sha' kurma atau sya'ir, maka para sahabat mengelurkan zakat fitrah sebesar setengah Sha' gandum pada masa mereka. Ibnu al-Mundir berkata: Saya tidak pernah tahu hadis Nabi yang menjelaskan tentang zakat fitrah dibayar dengan gandum, karena pada masa Nabi di Madinah gandum masih langka. Tapi, pada masa sahabat gandum banyak ditemukan di Madinah dan mereka berpendapat bahwa setengah Sha' gandum sama dengan satu Sha' kurma atau sya'ir. ( Yusuf Al-Qardhawi, 192)

Kelima, Pencatatan akad nikah, dimana di masa awal Islam nikah tidak perlu dicatat secara resmi. Hal ini karena pada masa sekarang sedikit sekali orang yang amanah yang bisa memenuhi hak isteri, selain itu adanya kebutuhan akan buku catatan nikah. Hakim memerlukan bukti berupa buku catatan nikah ketika timbul permasalah atau perselisihan antara suami isteri sehingga hak dan kewajiban masing-masing, baik isteri, suami, dan anak dapat dilindungi. Di Indonesia ada kewajiban untuk mencatatkan 
akad nikah di pejabat yang berwenang sesuai dengan regulasi yang berlaku dan sejak 2018 istilah yang digunakan adalah pencatatan perkawinan sesuai dengan PMA. ( Peraturan Menteri Agama No. 19 Tahun 2018 Tentang Pencatatan Perkawinan)

\section{PEMBAHASAN}

\section{Fleksibelitas Hukum Ekonomi Syariah}

Dalam bidang ekonomi berlaku juga pembagian hukum seperti di atas, artinya hukum ekonomi diklasifikasikan menjadi dua, yaitu; hukum ekonomi yang bersifat statis (tetap) tidak bisa berubah, dan hukum ekonomi yang bersifat fleksibel (dinamis), bisa berubah sesuai dengan perubahan tempat, waktu, dan keadaan. Dan klasifikasi kedua ini merupakan mayoritas dari hukum ekonomi karena ekonomi merupakan bagian dari muamalah dan hukum asal dari muamalah adalah boleh (ibāhah).

Hukum ekonomi yang bersifat statis (tetap) adalah hukum ekonomi yang didasarkan pada dalil-dalil nash yang tetap, tidak menerima takwil ataupun tafsir. Ketetapan hukum ini bertujuan untuk ketenteraman hidup dan kedamaian masyarakat. Merubah ketetapan ini dapat menjadikan keguncangan dan ketidakstabilan masyarakat. Diantara contoh hukum statis dalam bidang ekonomi adalah hukum pemilikan individu yang telah ditetapkan Islam, hukum waris, perbedaan orang dalam rizki, kewajiban zakat, kewajiban menafkahkan harta di jalan Allah, larangan berlebihan dan membadzir, larangan riba, larangan memakan harta orang lain dengan cara batil dan hukum yang lain. Semua itu merupakan hukum ekonomi yang telah ditetapkan Allah untuk keberlangsungan hidup manusia dan untuk ketenteraman masyarakat. (Yusuf al-Qardhawi, 20)

Sedangkan hukum ekonomi yang bersifat fleksibel (dinamis) merupakan hukum ekonomi yang bisa berubah sesuai dengan perubahan tempat, waktu dan keadaan. Hukum ekonomi yang fleksibel ini didasarkan pada hasil ijtihad para ahli fikih dan ahli fatwa. Hukum ekonomi yang fleksibel akan berubah sesuai dengan perubahan tempat, waktu dan keadaan. Allah SWT tidak ingin mempersulit hamba-Nya dengan nash-nash yang jelas, namun Allah SWT membiarkan persoalan-persoalan ekonomi tanpa nash. Terkadang Allah SWT menjelaskan persoalan ekonomi dengan nash mujmal (global) sehingga ada ruang untuk berijtihad.

Dalam sebuah hadis dijelaskan bahwa: "Sesungguhnya Allah telah menentukan had (batasan), maka janganlah kalian melampaui. Sesungguhnya Allah telah menetapkan kewajiban, maka janganlah kalian mensia-siakan. Sesungguhnya Allah telah mengharamkan sesuatu, maka janganlah kalian menerjangnya. Dan sesungguhnya Allah meninggalkan beberapa perkara (tidak 
mengaturnya) sebagai rahmat bagi kalian, maka janganlah kalian mencari dan membahasnya." (HR. Dar al-Quthni)

Kewajiban, keharaman, dan had (batasan) yang sudah ditetapkan Allah SWT merupakan aturan yang telah ditentukan untuk membangun sistem Islam. Sedangkan perkara lain yang tidak disebutkan Allah dengan jelas merupakan rahmat dari Allah SWT untuk kita semua. Allah SWT telah mempersilahkan kita untuk melakukan percobaan dan mempraktikan bagi kemajuan manusia. Diantara contohnya adalah: Cara memanfaatkan tanah pertanian bagi orang yang tidak memiliki. Tanah pertanian bisa dikelola dengan cara dipinjamkan, disewakan atau dengan akad Muzaraah. Contoh lain, mewajibkan pajak ke atas orang yang mampu untuk menutup defisit anggaran, tetapi cara membayar pajak, besaran pajak, dan bentuk pajak tidak ditentukan dengan pasti. Hal ini bisa berbeda sesuai dengan perbedaan tempat, waktu dan keadaan. Umar pernah mewajibkan cukai $10 \%$ (usyur) ke atas pedagang non-muslim yang masuk kawasan Islam (Monzer Kahf, 2009: 49)

Banyak sekali contoh praktik kaidah "Perubahan hukum Islam sebab perubahan tempat dan waktu" dalam bidang ekonomi (muamalah). Diantara contoh praktik dan penjelasannya adalah:

Pertama, Pembagian tanah hasil perang

Sahabat Bilal berpendapat: Sesungguhnya tanah negeri Syam yang telah ditaklukkan harus dibagi untuk para pasukan yang ikut berperang. Bilal melakukan itu karena mengikuti perilaku Rasulullah yang membagi tanah Khaibar setelah ditaklukkan dan juga berdalil dengan ayat yang menjelaskan tentang harta Ghanimah (QS. Al-Anfal: 41). Namun Umar tidak membagikan tanah tersebut, tanah itu tetap menjadi milik pemilik asalnya, namun mereka diwajibkan untuk membayar kharraj (pajak tanah). Pendapat Umar ini bertujuan untuk kemaslahatan kaum Muslimin di masa akan datang dan menjadi simpanan bagi generasi akan datang.

Perkataan Umar yang popular tentang hal ini adalah: Bagaimana dengan kaum Muslimin yang akan datang nanti? Mereka mendapati tanah dan bangunan yang ada sudah dibagi dan diwarisi dari orang tua mereka? Lalu Abdurahman bin Auf berkata kepada Umar: Apa pendapatmu, wahai Umar? Umar menjawab: Sesungguhnya tanah dan bangunan hasil perang adalah harta Fai', bukan Ghanimah sehingga tidak boleh dibagi, tanah dan bangunan tersebut untuk anak turun kita serta untuk para janda (Muhammad Baltaji, 1998: 124)

Keputusan Umar ini berdampak besar bagi perekonomian setelahnya karena tanah dan bangunan masih dimiliki oleh para pemilik asal, dengan catatan mereka harus membayar kharraj (pajak tanah).

Kedua, Menghidupkan tanah mati (Ihya' al-Ardh al-Mawat) 
Rasulullah SAW bersabda: "Barang siapa menghidupkan (merawat dan memakmurkan) tanah mati yang tidak dimiliki oleh seorang pun, maka tanah tersebut menjadi miliknya."

Umar menjalankan hadis ini hingga masa kekhalifahan beliau, namun ketika ada sebagian orang menguasai tanah mati dengan cara memagar dan membiarkannya bertahun-tahun tanpa ditanami, dan juga tidak meminta orang lain untuk menanaminya, maka Umar pun berpidato: "Barang siapa menghidupkan (memakmurkan) tanah mati, maka tanah itu menjadi haknya, dan tidak ada hak bagi orang yang menguasai tanah mati (tanpa ditanami) setelah tiga tahun." (Muhammad Baltaji, 1998: 199). Umar telah memberi batas selama tiga tahun bagi orang yang menguasai tanah mati, namun tidak dimakmurkan, batasan itu tidak disebutkan Nabi. Batasan Umar itu bertujuan agar tanah mati yang sudah dikuasai seseorang tapi tidak dimakmurkan dikembalikan menjadi milik umum (Negara) sehingga orang lain bisa memakmurkan tanah mati tersebut. Hal ini karena tanah merupakan salah satu faktor produksi yang diperlukan masyarakat sehingga tidak dapat dikuasi oleh seseorang dengan tanpa dikelola.

Ketiga, Zakat untuk Muallafah Qulubuhum

Pada masa Rasulullah SAW dan Abu Bakar, golongan Muallaf (orang yang baru masuk Islam atau yang diharapkan masuk Islam) masih mendapat bagian dari harta zakat karena mereka termasuk delapan golongan yang berhak mendapat bagian zakat (QS. Al-Taubah: 60). Tapi, pada masa Umar bagian zakat untuk mereka diberhentikan. (Yusuf AlQardhawi, 194)

Dikisahkan bahwa pada masa Abu Bakar, ada dua lelaki yang datang kepada beliau dan meminta tanah pekarangan dengan berkata: Sesungguhnya di dekat kami ada tanah yang tidak terawat, alangkah baiknya jika engkau memberikan tanah itu kepada kami. Lalu Abu Bakar menetapkan tanah tersebut untuk mereka berdua (Umar tidak mendengar kejadian itu). Ketika Umar mendengar kejadian itu, Umar berkata kepada dua lelaki: "Sesungguhnya Rasulullah mengharapkan hati kalian tetap dalam agama Islam dengan cara memberi (bagian zakat) karena saat itu Islam masih lemah. Ketahuilah bahwa sesungguhnya Allah telah memuliakan Islam pada hari ini. Pergilah kalian berdua, bekerjalah sebagaimana kaum Muslimin yang lain bekerja. Sesungguhnya kebenaran hanya ada di sisi Allah, barang siapa dikehendaki Allah, maka ia akan beriman dan barang siapa dikehendaki Allah, maka ia akan tetap kufur. Lalu dua lelaki itu kembali kepada Abu Bakar dan melaporkan perkataan Umar itu. Dan Abu Bakar menyetujui pendapat Umar (tidak memberi bagian zakat pada golongan Muallaf) dan menarik balik tanah yang diberikan. Lalu dua lelaki itu berkata: Yang menjadi Khalifah itu Anda atau Umar?! Abu Bakar menjawab: Dia (Umar). (Muhammad Baltaji, 1998: 169) 
Keempat, Cukai perdagangan

Zakat perdagangan diwajibkan untuk para pedagang Muslim, tapi tidak wajib bagi pedagang non-Muslim. Pedagang non-muslim hanya dibebani Jizyah (pajak diri) dan itu berlaku hingga masa pemerintahan Abu Bakar. Pada masa Umar, Abu Musa al-Asy'ari menulis surat kepada Umar yang isinya: "Sesungguhnya para pedagang Muslim ketika masuk ke Dar al-Harb (kawasan yang belum ditaklukkan umat Islam), mereka diminta membayar Usyur (10\% dari nilai barang perdagangan)," lalu Umar membalas surat Abu Musa, beliau menulis: “Ambil dari mereka (pedagang non-muslim) sebesar Usyur (10\%) ketika mereka masuk ke kawasan kita, dan ambillah dari para pedagang Ahli Dzimmah separuhnya (5\%). (Muhammad Baltaji, 1998: 449)

Cukai perdagangan sebesar $10 \%$ untuk pedagang non-Muslim yang ditetapkan Umar merupakan tindak balas terhadap mereka yang memberlakukan cukai $10 \%$ pada pedagang Muslim. Namun Umar memberlakukan kebijakan itu kepada pedagang yang barang dagangnya mencapai 200 Dirham dan itu diwajibkan hanya setahun sekali. Ini karena, jika cukai $10 \%$ ditetapkan pada barang perdagangan setiap masuk, maka akan berpengaruh pada harga. Umar juga tidak memberlakukan cukai 10\% untuk barang kebutuhan pokok bagi masyarakat Muslim. Kebijakan Umar ini diberlakukan untuk mewujudkan kemaslahatan umum bagi umat manusia serta untuk memenuhi tersedianya barang di pasar. (Muhammad Baltaji, 1998: 450-451)

Kelima, Membentuk Diwan (Baitul Mal)

Ide pembentukan Diwan (Baitul Mal) disampaikan oleh al-Walid bin Hisyam bin al-Mughirah, dia berkata kepada Umar: "Saya telah datang ke negeri Syam, dan saya melihat Raja-nya telah mendirikan Diwan (untuk mencatat keuangan Negara) dan juga telah mengatur tentara, maka lakukanlah seperti itu, wahai Umar! Lalu Umar mengumpulkan Uqail bin Abu Thalib, Makhramah bin Naufal, dan Jubair bin Math'am (dari suku Quraisy), dia berkata: Tetapkanlah orang sesuai dengan kedudukan mereka!! Lalu mereka memulai dari Bani Hasyim, lalu Abu Bakar dan kaumnya, lalu Umar dan kaumnya. Dan ketika Umar melihat urutan yang ditetapkan, dia berkata: Saya senang, urutan sebenarnya adalah seperti itu. Namun, mulailah dari yang paling dekat dengan Rasulullah, lalu setelahnya dan setelahnya sehingga kalian meletakkan Umar pada posisi yang diridhai Allah (Muhammad Baltaji, 1998: 462)

Diwan (Baitul Mal) dibentuk Umar pada tahun $20 \mathrm{H}$ dan ini merupakan ide baru dalam Negara Islam yang belum pernah terjadi pada pasa Rasulullah maupun masa Abu Bakar. Ide ini diambil dari pengalaman kerajaan Persia dan Romawi yang selalu bermusuhan dengan tentara Islam pada masa itu. (Muhammad Baltaji, 1998: 463) Diwan (Baitul Mal) dibentuk 
dengan tujuan untuk mengatur keuangan Negara agar kemaslahatan kaum Muslimin terwujud.

\section{KESIMPULAN}

Dari penjelasan di atas dapat disimpulkan bahwa hukum Islam dibagi menjadi dua; hukum Islam yang bersifat statis (tetap) dan hukum Islam yang bersifat fleksibel (dinamis). Hukum Islam statis merupakan hukum Islam yang didasarkan pada nash qath'i dan bersifat tetap, sedangkan hukum Islam fleksibel merupakan hukum Islam yang didasarkan pada nash dzanni, tidak ada dasar nash-nya, dan tidak ada ijma' ulama, dengan kata lain hukum Islam yang dihasilkan dari ijtihad.

Ada dua hal yang menyebabkan hukum Islam, khususnya hukum ekonomi syariah bersifat fleksibel, yaitu: pertama: perubahan Urf (adat kebiasaan) dan kedua, sikap masyarakat yang meremehkan hukum Islam. Untuk hukum Islam yang statis tidak bisa berubah meskipun diterapkan di waktu dan tempat yang berbeda.

Banyak contoh tentang fleksibelitas hukum ekonomi syariah yang terjadi sejak masa kekhalifahan, diantaranya adalah: Umar menghentikan pembagian tanah hasil peperangan, padahal Rasulullah telah membagikan tanah tersebut; Umar menghentikan bagian harta zakat bagi golongan Muallaf meskipun mereka termasuk delapan golongan yang berhak mendapat bagian zakat. Contoh lain adalah, Umar mendirikan Diwan (Baitul Mal) meskipun itu tidak pernah ada di masa Rasulullah dan masih banyak lagi contoh yang bisa dirujuk pada buku-buku karya ulama terdahulu. Wallahu a'lam 


\section{DAFTAR PUSTAKA}

Athiyah, Jamaluddin, (2003), Nahwa Taf il Maqashid al-Syariah. Damaskus: Dar al-Fikr.

Auda, Jaser, (2012), Maqashid al-Syariah ka Falsafah li al-Tasyri' al-Islami. USA: The International Institute of Islamic Thought.

Baltaji, Muhammad, (1998), Manhaj Umar Bin Al-Khattab Fi Al-Tasyri'. Kairo: Maktabah al-Sabab.

Ibnu Rusyd, Abu Walid Muhammad. Bidayah al-Mujtahid wa Nihayah alMuqtasid. Kairo: Dar al-Kutub al-Arabiyah, t.t.

Jauziyah, Ibnu al-Qayyib, (1998), I' lam al-Muaqqi' in an Rab al-Alamin. Bairut: Dar al-Fikr.

Kahf, Monzer, (2009), Daur al-Siyasah al-Maliyah wa Dzawabithaha fi Ithar alIqtishad al-Islami. Kuala Lumpur: The International Institute of Islamic Thought.

Mas'ud, Muhammad Khalid, (1999), Filsafat Hukum: Studi Tentang Pemikiran Abu Ishaq al-Syathiby. Bandung: Pustaka Madani.

Peraturan Menteri Agama No. 19 Tahun 2018 tentang Pencatatan Perkawinan.

Qarafi, Sihabuddin, (1987), al-Furuq. Kairo: Dar al-Salam.

Qardhawi, Yusuf, (2001), Daur al-Qiyam wa al-Akhlak fi al-Iqtishad al-Islami. Kairo: Maktabah Wahbah.

Qardhawi, Yusuf, (1993), Madkhal li Dirasah al-Syariah al-Islamiyah. Bairut: Muassasah al-Risalah.

Syarifuddin, Amir, (2011), Ushul Figh I. Jakarta: Kencana.

Wello, Abd. Malik, (2010), "Karakteristik dan Kedudukan Hukum Islam," Jurnal al-Risalah, Mei.

Zaidan, Abdul Karim, (1992), al-Madkhal li Dirasah al-Syariah al-Islamiyah. Baghdad: Maktabah al-Quds.

Zarqa, (2002), al-Madkhal fi al-Figh al-Am. Kairo: Maktabah al-Ilmiyah.

Zuhaily, Wahbah, (1996), Ushul al-Figh al-Islami. Damaskus: Dar al-Fikr. 